\title{
To Those Who Don The White Coat
}

\section{Cuckoo Choudhary, MD}

Don't lose your idealism

At least, don't let it be snatched

If at all it seems at some point that you have to lose it, drag the process along

Let it be slow, cling on to what you believe in

Your road will be tough

You may not be able to "attain" certain things, but you will certainly achieve

Remember that your coat stands for

Responsibility

Hard work

Display of warmth and affection

Patience

Putting others before your own self

Believing that holding a person's hand is the most important thing in the world when they are scared

Hoping even when there is no hope

And at times, not speaking the bare "truth" without lying

Continuing to believe that one person can make a difference in this world

A small difference may be, albeit a difference

But above all, remind yourself that your white coat stands for privilege

Yes, the privilege to study the art and science of medicine, and to use it everyday

It is a privilege to know the privileged information of fellow human beings

Respect that privilege

And then, and only then, will the "white coat" respect you! 